\title{
Invisible Microscopic Endometriosis: How Wrong Is the Sampson Hypothesis of Retrograde Menstruation to Explain the Pathogenesis of Endometriosis?
}

\author{
T.M. D'Hooghe \\ Editor-in-Chief, Gynecologic and Obstetric Investigation
}

In this issue of Gynecologic and Obstetric Investigation, the review of David Redwine clearly shows that invisible microscopic endometriosis, if well defined and well examined, is very rare [1]. Similar findings have been found in baboons [2], primates with spontaneous endometriosis that represent the best nonhuman primate model to study the pathogenesis of endometriosis [3]. The clinical and scientific impact of these observations is important for our understanding of endometriosis.

Clinically, in spite of the scant evidence reviewed by Redwine [1], the presence of microscopic endometriosis in visually normal pelvic peritoneum has become generally accepted. According to this concept, invisible microscopic endometriosis cannot be diagnosed or removed during surgery. Therefore, postoperative hormonal treatment with GnRH analogues is supposedly 'needed' to 'suppress' invisible microscopic endometriosis after laparoscopic removal of macroscopically visible endometriosis. Furthermore, the presence of invisible microscopic endometriosis has been used to explain the recurrence of endometriosis after laparoscopic surgery: 'what cannot be seen cannot be removed'. Since invisible microscopic endometriosis is rare [1], it seems more logical that the recurrence of endometriosis can be explained by incomplete surgery or by the establishment of new endometriotic lesions. We disagree with Redwine [1] that the recur- rence of endometriosis is very rare. In our own center, we reported a $50 \%$ cumulative recurrence rate of endometriosis within 2 years after surgery in referred patients with moderate-to-severe endometriosis and infertility and/or pelvic pain, who had been operated at Leuven University Center, a tertiary referral center for endometriosis research and treatment in Europe [4]. In view of the evidence reviewed by Redwine, invisible microscopic endometriosis is no longer an acceptable basis to justify postoperative hormonal treatment or to explain the recurrence of peritoneal endometriosis.

Scientifically, the rarity of microscopic endometriosis challenges the widely accepted Sampson theory that retrograde menstruation, transtubal migration and subsequent implantation of menstrual endometrial cells onto the pelvic peritoneum lead to the development of peritoneal endometriosis [5]. So far, there is no evidence in vivo or in vitro that endometrial cells that are present in the peritoneal fluid (PF) during menstruation can attach to and invade autologous pelvic peritoneum. Furthermore, a critical analysis of the literature has shown that endometrial cells are rather infrequently present in peritoneal fluid at the time of menstruation or during the nonmenstrual phases of the cycle [6]. Since endometrial cells are rarely present in PF, since there is no evidence that these endometrial cells from PF can implant and invade the

\begin{tabular}{ll}
\hline KARGER & ( ) 2003 S. Karger AG, Basel \\
$\begin{array}{l}\text { Fax + 41 61 306 1234 } \\
\text { E-Mail karger@karger.ch } \\
\text { www.karger.com }\end{array}$ & $\begin{array}{l}\text { Accessible online at: } \\
\text { www.karger.com/goi }\end{array}$
\end{tabular}


pelvic peritoneum, and since microscopic endometriosis is also rare, the validity of the Sampson theory can be questioned. Alternatively, it is still possible that large fragments of PF endometrial tissue implant onto pelvic peritoneum immediately after retrograde menstruation (without intermediate suspension in PF) and lead to the development of endometriotic lesions. There is also no evidence that pelvic inflammation during menstruation in women [7] and in nonhuman primates [8] induces the formation of endometriotic lesions through peritoneal metaplasia (induction theory). Clearly, more research is needed to evaluate the quantity and quality of endometrial cells and fragments in PF from women with and without endometriosis before the exact role of retrograde menstruation in the pathogenesis of endometriosis can be confirmed and understood.

\section{References}

1 Redwine DB: 'Invisible' microscopic endometriosis: A review. Gynecol Obstet Invest 2003; 55:63-67.

2 D'Hooghe TM, Bambra CS, De Jonge I, Machai PN, Korir R, Koninckx PR: A serial section study of visually normal posterior pelvic peritoneum from baboons with and without spontaneous endometriosis. Fertil Steril 1995; 63:1322-1325.

3 D'Hooghe TM: Clinical relevance of the baboon as a model for the study of endometriosis. Fertil Steril 1997;68:613-625.
4 D’Hooghe TM, Denys B, Spiessens C, Meuleman $\mathrm{C}$, Debrock S: Increased endometriosis recurrence rate after ovarian hyperstimulation? Oral presentation at the 18th Annual Meeting of the European Society for Human Reproduction and Embryology, Vienna, Austria, June 30-July 3rd, 2002.

5 Sampson JA: Peritoneal endometriosis due to the menstrual dissemination of endometrial tissue into the peritoneal cavity. Am J Obstet Gynecol 1927; 14:422-469.

6 D'Hooghe TM, Debrock S: Future directions in endometriosis research. Obstet Gynecol Clin N Am 2003; in press.
7 Debrock S, Drijkoningen M, Goossens W, Meuleman C, Hill JA, D'Hooghe TM: Quantity and quality of retrograde menstruation: Red blood cells, inflammation and peritoneal cells. Annual Meeting of the American Society for Reproductive Medicine, San Diego, 2000.

8 D'Hooghe TM, Bambra CS, Xiao L, Peixe K, Hill JA: Effect of menstruation and intrapelvic injection of endometrium on inflammatory parameters of peritoneal fluid in the baboon. Am J Obstet Gynecol 2001;184:917-925. 